\title{
Meta-topolin: an alternative for the prevention of oxidative stress in sugarcane micropropagation
}

\author{
- 2 Lindomar Maria de Souza ${ }^{1,4}$, Marina Medeiros de Araújo Silva ${ }^{2}$, Luciana Herculano $^{3}$,

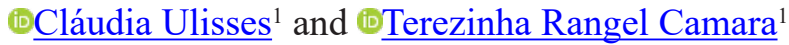

Received: 28 December 2018; accepted: 26 July 2019

How to cite: Souza, L.M., Silva, M.M.A., Herculano, L., Ulisses, C. \& Camara, T.R. 2019. Meta-topolin: an alternative for the prevention of oxidative stress in sugarcane micropropagation. Hoehnea 46: e1072018. http://dx.doi.org/10.1590/22368906-107/2018.

\begin{abstract}
Meta-topolin: an alternative for the prevention of oxidative stress in sugarcane micropropagation). The influence of two aromatic cytokinins (CKs), 6-benzylaminopurine (BAP) and meta-topolin $(m \mathrm{~T})$, on in vitro propagation and redox metabolism of sugarcane (Saccharum spp., variety RB98710) was investigated. Plants were cultured in Murashige and Skoog (MS) medium supplemented with $m \mathrm{~T}\left(5 \mu \mathrm{mol} . \mathrm{L}^{-1}\right)$ or BAP $\left(5\right.$ or $\left.6.66 \mu \mathrm{mol} . \mathrm{L}^{-1}\right)$ for 40 days. The use of $m \mathrm{~T}$ provided an increase in the multiplication rate and stem length of plants and shoots when compared to BAP. Shoots generated from the $m \mathrm{~T}$ treatment presented low malondialdehyde (MDA) content and superoxide dismutase (SOD) activity, although they had higher hydrogen peroxide $\left(\mathrm{H}_{2} \mathrm{O}_{2}\right)$ content. Thus, the $\mathrm{H}_{2} \mathrm{O}_{2}$ did not act as a stress marker, but it is related to plant growth and development processes.
\end{abstract}

Keywords: antioxidative enzymes, cytokinins, $\mathrm{H}_{2} \mathrm{O}_{2}$, Saccharum spp.

RESUMO - (Meta-topolina: uma alternativa para a prevenção do estresse oxidativo na micropropagação da cana-de-açúcar). A influência de duas citocininas aromáticas (CKs), 6-benzilaminopurina (BAP) e meta-topolina ( $m$ T) na propagação in vitro e no metabolismo redox da cana-de-açúcar (Saccharum spp., variedade RB98710) foi investigada. As plantas foram cultivadas em meio Murashige e Skoog (MS) suplementado com $m$ T $\left(5 \mu \mathrm{mol} . \mathrm{L}^{-1}\right)$ ou BAP (5 ou 6,66 $\mu \mathrm{mol}^{\left.-L^{-1}\right)}$ por 40 dias. O uso de $m \mathrm{~T}$ proporcionou aumento na taxa de multiplicação e no comprimento do caule das plantas e brotações quando comparado ao cultivado com BAP. Os brotos gerados a partir do tratamento com $m$ T apresentaram baixo teor de malondialdeído (MDA) e atividade de superóxido dismutase (SOD), apesar de apresentarem maior teor de peróxido de hidrogênio $\left(\mathrm{H}_{2} \mathrm{O}_{2}\right)$. Assim, $\mathrm{o}$ $\mathrm{H}_{2} \mathrm{O}_{2}$ não atuou como marcador de estresse, mas tem relação com os processos de crescimento e desenvolvimento das plantas. Palavras-chave: citocininas, enzimas antioxidantes, $\mathrm{H}_{2} \mathrm{O}_{2}$, Saccharum spp.

\section{Introduction}

Commercial-scale micropropagation of sugarcane (Saccharum spp.) is already a reality in the agrotechnological sector. This process allows a quick multiplication of newly released varieties, production of uniform and disease-free plants, and high cane productivity and sugar yield (Dobhal et al. 2013, Hasner et al. 2019). The 6-benzylaminopurine (BAP) is an important aromatic cytokinin (CK) that is routinely utilized in micropropagation systems, and its effectiveness has been described to different species (Malá et al. 2013, Nower 2014, Gutiérrez et al. 2019).
Although of the benefits on multiplication, high concentrations or prolonged exposure to cytokinins (CKs) can lead to stress conditions that limit the in vitro micropropagation, due to the occurrence of morphophysiological disorders (Razani et al. 2019). Thus, another aromatic CK, meta-topolin $(m \mathrm{~T})$ appears to be more advantageous in improving shoot proliferation while reducing or even alleviating some of the adverse effects encountered with the use of BAP (Aremu et al. 2012, Malá et al. 2013, Amoo et al. 2014).

There have been some studies on how artificial environment in culture in vitro, especially by the use

1. Universidade Federal Rural de Pernambuco, Rua Dom Manuel de Medeiros, s/n, Dois Irmãos, 52171-900 Recife, Pernambuco, Brasil

2. Instituto Federal de Rondônia , Avenida Vereador Otaviano Pereira Neto, 874, St. 2, 6890-000 Jaru, Rondônia, Brasil

3. Universidade Federal do Ceará, Avenida da Universidade, 2853, Benfica, 60020-181 Fortaleza, Ceará, Brasil

4. Corresponding author: lindomarsouza.ufrpe@gmail.com 
of exogenous plant growth regulators (PGRs), affect antioxidative enzyme activity about plant tissue growth and multiplication (Díaz-Vivancos et al. 2011, Amoo et al. 2014, 2015). This occurs due to the increased production and accumulation of reactive oxygen species (ROS) such as hydrogen peroxide $\left(\mathrm{H}_{2} \mathrm{O}_{2}\right)$ (Gupta 2010). Some studies have found that ROS play an important role in plant growth and development through cellular signaling (Carol \& Dolan 2006, Bat'ková et al. 2008, Mabuchi et al. 2018, Smirnoff \& Arnald 2018, Waszczak et al. 2018). This research had as objective to analyze the influence of $m \mathrm{~T}$ and BAP on redox metabolism and in vitro propagation of sugarcane (variety RB 98710).

The variety RB98710 was developed by the Brazilian Interuniversity Network for the Development of Sugarcane Industry - RIDESA, and shows high sucrose content and agricultural production, as well as low fiber content and precocious maturation.

\section{Material and methods}

The study was carried out in the Plant Tissue Culture Laboratory (PTCL) at the Federal Rural University of Pernambuco, Recife, Brazil.

Plants of variety RB98710 previously established in vitro were cultivated in flasks containing $20 \mathrm{~mL}$ of liquid MS (Murashige \& Skoog 1962) medium with $5 \mu$ mol.L $L^{-1}$ of two different cytokinins (CKs) 6-benzylaminopurine (BAP) and $m \mathrm{~T}$ (meta-topolin). A third treatment containing $6.66 \mu$ mol. $\mathrm{L}^{-1}$ of BAP was used as a control since it is commonly used for sugarcane micropropagation. Cultures were incubated in a growth room at $25 \pm 2{ }^{\circ} \mathrm{C}$ and $16 \mathrm{~h}$ photoperiod (irradiance of $40 \mu \mathrm{mol} \mathrm{m}{ }^{-2} \mathrm{~s}^{-1}$ provided by white fluorescent lamps) for 40 days.

Growth and biochemical measurements were done in plants and shoots. The fresh weight and stem length of plants and shoots were expressed in terms of the increment (last - initial). The number of shoots per plant was also evaluated.

The content of $\mathrm{H}_{2} \mathrm{O}_{2}$ was analyzed according to Alexieva et al. (2001). Lipid peroxidation was measured in terms of MDA levels according to Heath \& Packer (1968). Enzymatic activity analyses were carried out using $0.1 \mathrm{~g}$ of fresh leaf samples followed by homogenization in potassium phosphate buffer $100 \mathrm{mM}$ (pH 7.5) containing $1 \mathrm{mM}$ EDTA and $3 \mathrm{mM}$ DTT (threo-1,4-Dimercapto-2,3-butanediol). The homogenate was centrifuged at $10.000 \mathrm{~g}$ and $4{ }^{\circ} \mathrm{C}$ for 15 minutes and the supernatant obtained was used for spectrophotometric quantification performed in triplicate. Total protein content was measured by the Bradford method (1976). The specific activities of superoxide dismutase (SOD, EC 1.15.1.1), catalase (CAT, EC 1.11.1.6), and ascorbate peroxidase (APX, EC 1.11.1.11) were measured according to Giannopolitis \& Ries (1977), Havir \& Mchale (1987) and Nakano \& Assada (1981), respectively.

A completely randomized design was adopted, with three treatments and ten repetitions. The experimental unit consisted of a flask containing three plants. The data were analyzed by ANOVA and the means were compared by Tukey's test using the software Assistat v. 7.7 beta (Silva 2012).

\section{Results and Discussion}

Cytokinins (CKs) promoted different responses to plants and shoots growth (table 1). The fresh weight was highest in shoots cultured in the presence of $5 \mu \mathrm{mol} . \mathrm{L}^{-1} m \mathrm{~T}$ and BAP. The use of $m \mathrm{~T}$ promoted a higher stem length of plants and shoots and increased the number of shoots formation of shoots (table 1).

The $\mathrm{H}_{2} \mathrm{O}_{2}$ content was higher in plants cultivated with $5 \mu \mathrm{mol} . \mathrm{L}^{-1}$ of BAP, whereas the shoots had higher concentration of $\mathrm{H}_{2} \mathrm{O}_{2}$ with $5 \mu \mathrm{mol} . \mathrm{L}^{-1}$ of $m \mathrm{~T}$ (table 2). Regarding lipid peroxidation, represented by MDA levels, the plants cultivated with $m \mathrm{~T}$ had more MDA content when compared with plants cultivated to BAP (table 2).

However, in shoots, a lower MDA content was observed in those cultivated with $m \mathrm{~T}$. The highest number of shoots per plant induced by $m \mathrm{~T}$ was connected with a low activity of antioxidant enzymes when compared to the usual concentration of BAP (6.66 $\mu$ mol. $\left.\mathrm{L}^{-1}\right)$. Among the antioxidant enzymes studied, SOD showed the lowest activity in plants and shoots (table 2). Despite presenting low SOD activity, the shoots displayed high content of $\mathrm{H}_{2} \mathrm{O}_{2}$ (table 2). The highest CAT activity in plants and shoots was observed on the $6.66 \mu$ mol. $\mathrm{L}^{-1}$ concentration of BAP (table 2). In our study, the APX activity was higher in plants cultivated with BAP comparison to the medium with $m \mathrm{~T}$, but it was not statistically significant in shoots.

Shoots of Pelargonium hortorum growing on medium supplemented with $m \mathrm{~T}$, have had enhanced $\mathrm{H}_{2} \mathrm{O}_{2}$ production. This coincided with the higher activity of antioxidant enzyme and shoot formation (Wojtania \& Skrzypek 2014).

In the shoot culture of Cistus heterophyllus, the addition of BAP induced a significant increase in the free radical scavenging capacity (López-Orenes et al. 2013) and thus indicating that the CKs are involved in the regulation of plant growth and development as well as a stress response. 
Table 1 Fresh weight $(\mathrm{g})$ and length $(\mathrm{cm})$ of plants and shoots, and the number of shoots per plant in a variety of sugarcane (RB98710) cultivated in vitro with different cytokinins treatments $\left(\mu \mathrm{mol} . \mathrm{L}^{-1}\right)$ for 40 days.

\begin{tabular}{lccccc}
\hline \multirow{2}{*}{$\begin{array}{l}\text { Cytokinin } \\
\text { treatment }\end{array}$} & \multicolumn{2}{c}{ Fresh weight } & \multicolumn{2}{c}{ Length } & \multirow{2}{*}{ Shoot/Plant } \\
\cline { 2 - 5 } & Plants & Shoots & Plants & Shoots & \\
\hline $5 \mathrm{mT}$ & $0.35 \pm 0.02 \mathrm{a}$ & $0.08 \pm 0.004 \mathrm{a}$ & $7.12 \pm 0.30 \mathrm{a}$ & $6.31 \pm 0.13 \mathrm{a}$ & $2.00 \pm 0.13 \mathrm{a}$ \\
$5 \mathrm{BAP}$ & $0.27 \pm 0.02 \mathrm{a}$ & $0.10 \pm 0.006 \mathrm{a}$ & $1.15 \pm 0.08 \mathrm{c}$ & $4.37 \pm 0.08 \mathrm{c}$ & $1.33 \pm 0.13 \mathrm{~b}$ \\
$6.66 \mathrm{BAP}$ & $0.27 \pm 0.04 \mathrm{a}$ & $0.04 \pm 0.002 \mathrm{~b}$ & $4.43 \pm 0.63 \mathrm{~b}$ & $5.25 \pm 0.28 \mathrm{~b}$ & $1.08 \pm 0.15 \mathrm{~b}$ \\
\hline
\end{tabular}

Means \pm SE $(n=10)$. Different letters indicate significant differences $(p<0.05)$.

Table 2. Content Contents of $\mathrm{H}_{2} \mathrm{O}_{2}\left(\mu \mathrm{mol} \mathrm{g}{ }^{-1} \mathrm{FW}\right)$ and MDA (nmol g-1 $\left.\mathrm{FW}\right)$, and specific activities of SOD ( $\mathrm{U} \mathrm{mg}^{-1}$ protein), CAT (nmol $\mathrm{H}_{2} \mathrm{O}_{2} \mathrm{mg}^{-1}$ protein $\left.\mathrm{min}^{-1}\right)$, and APX $\left(\mu \mathrm{mol} \mathrm{AsA} \mathrm{mg}^{-1}\right.$ protein $\mathrm{min}^{-1}$ ) in sugarcane plants and shoots (RB98710) cultivated in vitro with different cytokinins treatments $\left(\mu \mathrm{mol} . \mathrm{L}^{-1}\right)$ for 40 days.

\begin{tabular}{lcccccc}
\hline & $\begin{array}{c}\text { Cytokinin } \\
\text { treatment }\end{array}$ & $\mathrm{H}_{2} \mathrm{O}_{2}$ & MDA & SOD & CAT & APX \\
\hline Plants & $5 \mathrm{mT}$ & $6.90 \pm 0.12 \mathrm{~b}$ & $4.05 \pm 0.20 \mathrm{a}$ & $0.52 \pm 0.08 \mathrm{~b}$ & $103.75 \pm 5.58 \mathrm{~b}$ & $332 \pm 0.14 \mathrm{~b}$ \\
& $5 \mathrm{BAP}$ & $7.52 \pm 0.12 \mathrm{a}$ & $3.30 \pm 0.15 \mathrm{~b}$ & $1.66 \pm 0.18 \mathrm{a}$ & $90.75 \pm 7.26 \mathrm{~b}$ & $482 \pm 0.19 \mathrm{a}$ \\
& $6.66 \mathrm{BAP}$ & $6.75 \pm 0.17 \mathrm{~b}$ & $2.87 \pm 0.06 \mathrm{~b}$ & $1.59 \pm 0.18 \mathrm{a}$ & $139.75 \pm 4.55 \mathrm{a}$ & $465 \pm 0.25 \mathrm{a}$ \\
Shoots & $5 \mathrm{mT}$ & $8.07 \pm 0.37 \mathrm{a}$ & $1.40 \pm 0.12 \mathrm{~b}$ & $0.95 \pm 0.15 \mathrm{c}$ & $81.25 \pm 6.44 \mathrm{~b}$ & $374 \pm 0.10 \mathrm{a}$ \\
& $5 \mathrm{BAP}$ & $6.50 \pm 0.23 \mathrm{~b}$ & $1.45 \pm 0.16 \mathrm{~b}$ & $2.09 \pm 0.08 \mathrm{~b}$ & $100.25 \pm 4.39 \mathrm{ab}$ & $378 \pm 0.25 \mathrm{a}$ \\
& $6.66 \mathrm{BAP}$ & $6.85 \pm 0.06 \mathrm{~b}$ & $2.95 \pm 0.10 \mathrm{a}$ & $3.36 \pm 0.07 \mathrm{a}$ & $117.50 \pm 5.07 \mathrm{a}$ & $378 \pm 0.14 \mathrm{a}$ \\
\hline
\end{tabular}

Means $\pm \operatorname{SE}(\mathrm{n}=4)$. Different letters indicate significant differences $(p<0.05)$.

Responses of growth similar to showing the favorable effects of topolins in micropropagation have also been recorded in other species, such as Scutellaria spp. and Pelargonium hortorum (Aremu et al. 2012, Brearley et al. 2014, Naaz et al. 2019).

Superior multiplication rates were recorded in plants of two banana cultivars in vitro. The plants cultivated with $m \mathrm{~T}$ and $m \mathrm{TR}$ (meta-topolin riboside) were major when compared to equimolar concentration BAP (Bairu et al. 2008).

The PGRs added into culture medium may cause changes in the physiology and biochemical of plant cells. Consequently, metabolic disturbances occur which promote the accumulation of ROS (Ozden \& Karaaslan 2011). The increase in ROS levels can induce growth inhibition, leading to inferior quality plant formation (Gupta 2010). Thus, growth and morphogenic responses of plants and shoots sugarcane may be related to changing in the equilibrium of redox reactions caused by CKs. The active production of $\mathrm{H}_{2} \mathrm{O}_{2}$ in the apoplast, catalyzed by oxidases NADPH dependent (Petrov \& Breusegem 2012) and peroxidases in the cell wall (Neill et al. 2002) is a prerequisite for normal development and growth of the plants (Petrov \& Breusegen 2012). The apoplastic origin of the $\mathrm{H}_{2} \mathrm{O}_{2}$ can explain the increased content of this ROS in shoots cultivated with $m \mathrm{~T}$. The apoplastic pathway of $\mathrm{H}_{2} \mathrm{O}_{2}$ formation is related to cell growth and expansion. Once in which the shoots displayed higher stem length.

A lower MDA content observed in shoots cultivated with $m$ T suggesting that cultivation with this $\mathrm{CK}$ induces better protection against oxidative damage. Also, it was confirmed that $\mathrm{H}_{2} \mathrm{O}_{2}$ accumulation is not always related to the peroxidation process.

For many years the $\mathrm{H}_{2} \mathrm{O}_{2}$ was described as an ROS capable of causing damage to the proteins, lipids, nucleic acids (Bienert et al. 2006) and supramolecular structures (Petrov \& Breusegem 2012). In the last decade, however, it was demonstrated that the $\mathrm{H}_{2} \mathrm{O}_{2}$ may act as a signaling molecule involved in multiple physiological functions (Mitller et al. 2011, Smirnoff et al. 2018), including cell division (Livanos et al. 2012).

In contrast to results obtained this investigation, the enhanced of shoot formation capacity in $P$. hortorum cultivated with $m \mathrm{~T}$, coincided with higher levels of $\mathrm{H}_{2} \mathrm{O}_{2}$, and activities of CAT and POD (Wojtania \& 
Skrzypek 2014). Therefore, CKs also can alter the levels of antioxidant enzymes in vitro plants, for example, in Crocus sativus (Díaz-Vivancos et al. 2011). Enzyme SOD constitutes the first line of plant defense, converting superoxide anion radical $\left(\mathrm{O}_{2}{ }^{*}\right)$ to $\mathrm{H}_{2} \mathrm{O}_{2}$, which is quickly metabolized by APX and CAT (Amoo et al. 2015). A low SOD activity and high content of $\mathrm{H}_{2} \mathrm{O}_{2}$ in shoots demonstrate that the dismutation of the $\mathrm{O}_{2}{ }^{-}$- is not the main source of $\mathrm{H}_{2} \mathrm{O}_{2}$ in the shoots sugarcane RB98710 when were cultivated with $m \mathrm{~T}$.

An increase in the activity of antioxidant enzymes with increased CK concentration was also reported in Merwilla plumbea (Amoo et al. 2015). According to López-Orenes et al. (2013), BAP stimulates the production of antioxidant compounds in cultivated shoots of $C$. heterophyllus, probably due to the stress originated by the addition of this phytoregulator in medium cultured. Obtained results indicated that CAT activity was the component of the antioxidative defense system involved in $\mathrm{H}_{2} \mathrm{O}_{2}$ detoxification that suffered more changes in response to the type and concentration of $\mathrm{CK}$ added in the culture medium.

\section{Conclusion}

Based on the data this research, $m \mathrm{~T}$ can be used as a potential alternative to BAP to in vitro propagation of sugarcane (var. RB98710), since it positively influences the growth and quality of the plants. The production and detoxification of ROS are modified by CKs. The low SOD activity, the lower MDA content, and the best means for the growth parameters in the shoots cultivated with $m$ T confirmed that $\mathrm{H}_{2} \mathrm{O}_{2}$ acted signaling in the processes of plant growth and development.

\section{Acknowledgments}

The authors thank the Biofactory Governor Miguel Arraes (CETENE, Recife, Brazil) for providing the sugarcane plants and Foundation for Science and Technology Support of Pernambuco (FACEPE) for scholarship funding.

\section{Literature cited}

Alexieva, V., Sergiev, I., Mapelli, S. \& Karanov, E. 2001. The effect of drought and ultraviolet radiation on growth and stress markers in pea and wheat. Plant, Cell \& Environment 24: 1337-134.
Aremu, A.O., Bairu, M.W., Doležal, K., Finnie, J.F. \&Van Staden, J. 2012. Topolins: A panacea to plant tissue culture challenges? Plant Cell, Tissue and Organ Culture 108: 1-16.

Amoo, S.O., Aremu, A.O., Moyo, M., Sunmonu, T.O., Plíhalová, L., Doležal, K. \& Van Staden, J. 2015. Physiological and biochemical effects of a tetrahydropyranyl-substituted meta-topolin in micropropagated Merwilla plumbea. Plant Cell, Tissue and Organ Culture 121: 579-590.

Amoo, S.O., Aremu, A.O., Moyo, M., Szücová, L., Doležal, K. \& Van Staden, J. 2014. Physiological effects of a novel aromatic cytokinin analogue in micropropagated Aloe arborescens and Harpagophytum procumbens. Plant Cell, Tissue and Organ Culture 116: 17-26.

Bairu, M.W., Stirk, W.A., Dolezal, K. \& Van Staden, J. 2008. The role of topolins in micropropagation and somaclonal variation of banana cultivars 'Williams' and 'Grand Naine' (Musa spp. AAA). Plant Cell, Tissue and Organ Culture 95: 373-379.

Bienert, G.P., Schjoerring, J.K. \& Jahn, T.P. 2006. Membrane transport of hydrogen peroxide. Biochimica et Biophysica Acta 1758: 994-1003.

Batkova, P., Pospisilova, J. \& Synkova, H. 2008. Production of reactive oxygen and development of antioxidative systems during in vitro growth and ex vitro transfer. Biologia Plantarum 52: 413-422.

Bradford, M.M. 1976. A rapid and sensitive method for the quantitation of microgram quantities of protein utilizing the principle of protein-dye binding. Analytical Biochemistry 72: 248-254.

Brearley, T.A., Vaidya, B.N. \& Joshee, N. 2014 Cytokinin, carbon source, and acclimatization requirements for in vitro propagation of Scutellaria barbata D. Don and Scutellaria racemosa Pers. American Journal of Plant Sciences 5: 3662-3672.

Carol, R. J. \& Dolan, L. 2006. The role of reactive oxygen species in cell growth: lessons from root hairs. Journal of Experimental Botany 57: 1829-1834.

Díaz-Vivancos, P., Majourhat, K., Fernández, J.A., Hernández, J.A. \& Piqueras, A. 2011. Study of the antioxidant enzymatic system during shoot development from cultured intercalar meristems of saffron. Plant Growth Regulation 65: 119-126.

Dobhal, U., Sharma, M.D., Singh, P., Sharma, E., Kumar, S. \& Gaur, A.K. 2013. Optimization of conditions for micropropagation of two commercial sugarcane cultivars CoPANT 03220 and CoPANT 05224. Journal of Cell \& Tissue Research 13: 3921-3926.

Giannopolitis, C.N. \& Ries, S.K. 1977. Superoxide dismutases: I. Occurrence in higher plants. Plant Physiology 59: 309-314.

Gupta, S.D. 2010. Role of free radicals and antioxidants in in vitro morphogenesis. In Reactive oxygen species and antioxidants in higher plants, ed. Gupta, Science Publishers, Kharagpur, pp. 229-247. 
Gutiérrez, B., Cobo, M.M., Orellana, M., Vega, J, Arahana, V., Jaramillo, V. \& Torres, M.L. 2019. Micropropagation of Solanum quitoense var. quitoense by apical bud, petiole and hypocotyl culture. Technology 36: 1-7.

Hasner, C., Lima, A.A. \& Winter, E. 2019. Technology advances in sugarcane propagation: a patent citation study. World Patent Information 56: 9-16.

Havir, E.A. \& McHale, N.A. 1987. Biochemical and developmental characterization of multiple forms of catalase in tobacco leaves. Plant Physiology 84: 450-455.

Heath, R.L. \& Packer, L. 1968. Photoperoxidation in isolated chloroplasts. Archives of Biochemistry and Biophysics 125: 189-198.

Livanos, P., Apostolakos, P. \& Galatis, B. 2012. Plant cell division. ROS homeostasis is required. Plant Signaling \& Behavior 7: 771-778.

López-Orenes, A., Ros-Marín, A.F., Ferrer, M.A. \& Calderón, A. A. 2013. Antioxidant capacity as a marker for assessing the in vitro performance of the endangered Cistus heterophyllus. Science World Journal 2013: 1-10.

Mabuchi, K., Maki, H., Itaya, T., Suzuki, T., Nomoto, M., Sakaoka, S., Morikami, A., Higashiyama, T., Tada, Y. \& Busch, W. 2018. MYB30 links ROS signaling, root cell elongation, and plant immune responses. Proceedings of the National Academy of Sciences 115: 4710-4719.

Malá, J., Máchová, P., Cvrčková, H., Karady, M., Novák, O., Mikulík, J., Dostál, J., Strnad, M. \& Doležal, K. 2013. The role of cytokinins during micropropagation of wych elm. Biologia Plantarum 57: 174-178.

Mittler, R., Vanderauwera, S., Suzuki, N., Miller, G., Tognetti, V.B., Vandepoele, K., Gollery, M., Shulaev, V. \& Breusegem, F.V. 2011. ROS signaling: the new wave? Trends in Plant Science 16: 300-309.

Murashige, T. \& Skoog, F. 1962. A revised medium for rapid growth and bioassays with tobacco tissue cultures. Plant Physiology 15: 473-497.
Nakano, Y. \& Asada, K. 1981. Hydrogen peroxide is scavenged by ascorbate-specific peroxidase in spinach chloroplasts. Plant and Cell Physiology 22: 1068-1072.

Naaz, A., Hussain, S., Anis, M. \& Alatar, A. 2019. Metatopolin improved micropropagation in Syzygium cumini and acclimatization to ex vitro conditions. Biologia Plantarum 63: 174-182.

Neill, S., Desikan, R. \& Hancock, J. 2002. Hydrogen peroxide signaling. Current Opinion in Plant Biology 5: 388-395

Nower, A.A. 2014. In vitro propagation and synthetic seeds production: an efficient method for Stevia rebaudiana Bertoni. Sugar Tech 169: 100-108.

Ozden, M. \& Karaaslan, M. 2011. Effects of cytokinin on callus proliferation associated with physiological and biochemical changes in Vitis vinifera L. Acta Physiologiae Plantarum 33: 1451-1459.

Petrov, V.D. \& Breusegem, F.V. 2012. Hydrogen peroxide a central hub for information flow in plant cells. AoB Plants 2012: 1-13.

Razani, M., Kayat, F., Redwan, R. M. \& Susanto, D. 2019. Effect of Somaclonal Variation in Musa acuminata cv. Berangan Through Micropropagation Using RAPD. Biotechnology 18: 9-14.

Silva, F.A.S. ASSISTAT: Versão 7.7 beta. DEAG-CTRNUFCG. Available in http://www.assistat.com/indexp. $\mathrm{html}$ (access in 10-VI-2012).

Smirnoff, N. \& Arnaud, D. 2018. Hydrogen peroxide metabolism and functions in plants. New Phytologist 221: 1197-1214.

Waszczak, C., Carmody, M. \& Kangasjärvi, J. 2018. Reactive Oxygen Species in Plant Signaling. Annual Review of Plant Biology 69: 209-236.

Wojtania, A. \& Skrzypek, E. 2012. Effects of cytokinins on antioxidant enzymes in in vitro growth shoots of Pelargonium hortorum L. H. Bayley. Acta Agrobotanica 67: 33-42. 